This is an electronic reprint of the original article. This reprint may differ from the original in pagination and typographic detail.

Author(s): Heikka, Taneli; Uskali, Turo; Valaskivi, Katja

Title: $\quad$ Crashing a National Media Event : Circulation of Social Imaginaries in the Gatecrashers Riots in Finland

Year: $\quad 2016$

Version:

Please cite the original version:

Heikka, T., Uskali, T., \& Valaskivi, K. (2016). Crashing a National Media Event :

Circulation of Social Imaginaries in the Gatecrashers Riots in Finland. In B. Mitu, \& S.

Poulakidakos (Eds.), Media Events : A Critical Contemporary Approach (pp. 92-113).

Palgrave Macmillan. https://doi.org/10.1057/9781137574282_6

All material supplied via JYX is protected by copyright and other intellectual property rights, and duplication or sale of all or part of any of the repository collections is not permitted, except that material may be duplicated by you for your research use or educational purposes in electronic or print form. You must obtain permission for any other use. Electronic or print copies may not be offered, whether for sale or otherwise to anyone who is not an authorised user. 
Chapter 6

\title{
Crashing a National Media Event:- The Circulation of Social Imaginaries in the Gatecrashers Riots in Finland
}

\author{
Taneli Heikka, Katja Valaskivi, and Turo Uskali
}

\section{Introduction}

'Elitists partied so we beat up a horse. We did what we had to do'.

- Meme mocking the Gatecrashers protestoers' use of violence.

On the-Finnish Independence Day, 6 December 2013, violence erupted at around $8.00 \mathrm{pm}$.

Rioters had just approached the barricades at the venue of the presidential ball venue-when they encountered the-mounted police. In a few chaotic seconds, the rioters slammed the police horses with ice hockey sticks and makeshift riot shields $s_{2}$ and threw stones at the policemen. Several video cameras captured the events in the dark and freezing Nordic night.

Physical injuries were few and minor, but the blows delivered to the rioters' cause were severe.

This chapter describes and analyses the interrelations of social media outlets and mainstream media coverage of the widely reported Gatecrashers media event. The riots in this case are those against the presidential festivities of Finnish Independence Day.

Demonstrations broke out in the city of Tampere on 6 December 6 , 2013. The rioters called themselves -Kiakkovieraat ${ }_{-}^{\prime}$ - a pun, which carries the double meaning of hockey guests or Gatecrashers.

We use the moment of violence described above as a nodal point for tracing the circulation of meanings on different media platforms, in different times and spaces. By tracing the circulation of the 'horse meme' in varying contexts and media platforms, it is possible to understand the power struggle between different social imaginaries at play during the Gatecrashers media event.

\section{Background}


The celebration of Independence Day in Finland on $\underline{6}$ December 6 is traditionally a serious, even solemn event. The presidential reception is aired live by the National Broadcasting Company YLE from the presidential residence in Helsinki. Decorated and revered WWH World War II veterans enter first to greet the president, followed by ministers, MPs, business elites, diplomats and a selection of 'ordinary people' the presidential couple has met over the year.

In 2013, the reception was held in the western city of Tampere due to renovation of the president's official residence. This change instigated a new role and type of mediated demonstration. Tampere is known as the city of industry and ice hockey enthusiasm. The rioters wore facemasks of iconic Finnish ice hockey players and used hockey sticks to direct blows at shop windows, people and animals. Some wore protective hockey gear. The cause of events was influenced by the fact that YLE was, for the third year, showing $t \mp$ weets with relevant hashtags during the Independence Day broadcast.

Understanding the significance of the media event and the circulating meanings related to the protests requires a short excursion into the history of Finland and the city of Tampere. Finnish independence from Russia was declared in 1917. A bloody civil war broke out in the aftermath. The city of Tampere was the theatre for fierce battles and was among the last strongholds for the 'red' (i.e. communist/radical social democratic) revolutionary forces, bloodily overcome by then commander-in-chief and later WWII World War II Marshal of Finland and President C._G._E Mannerheim. The ideological division of the city has been a recurring theme in public debate, lasting to date, sometimes declared overcome, sometimes raising its'- head in new, mediated forms.

When it was announced that the presidential reception would be moved to a new location, a group of anonymous protestoers declared several months ahead of the event - first on the Internet, then in mainstream media - their intention that they intended to disturb the festivities in Tampere. An array of cultural and historical references exploited and circulated in this announcement. The anonymous organizers welcomed the 'bourgeois elite' to Tampere, as it had been a while since the massacring white guards (of Mannerheim) had paid a visit. A class war was declared:- Aaccording to the organizers, differences between the ‘haves' and _have-nots' remained irreconcilable. 
As Tampere is known as the capital of ice hockey fanaticism in Finland, the protestoers claimed to be 'hockey guests' in at the party of the elite (Tampere dialect for hockey guest, ‘kiakkovieras’’, resembles the Finnish word ‘kuokkavieras- - a gatecrasher). They used hockey sticks as their weapons and hockey gear as their armour. Many of the anonymous protestoers used (Guy Fawkes-inspired) masks of the nationally famous hockey player Timo Jutila. In a bizarre reference to a well-known television sausage commercial in which the now retired and overweight Jutila had appeared, the protestoers adopted the slogan 'Let's barbeque!' as one of their mottos.

The Gatecrashers recycled the historical and nationalist social imaginary typical for Finland's Independence Day. The facets and references surrounding the event - a class/civil war; WWI-World War II veterans and resistance against Soviet attempts to occupying attempts; a forgone national consensus; masked, anonymous protestoers and the meaty wellbeing of a commercialized sport hero - provided for a perplexing mix of memes, news, blogs and analysis in the media.

\section{Theory}

In this chapter, we examine the interrelationship between social media and the mainstream media in the media event (cf. Dayan and Katz, 1992) from the perspective of circulation. Dayan and Katz's seminal work on media events helps us to understand the ceremonial and ritual aspects of a media event, in which television still has a significant role, although it is no longer the main locus of action.

Media events are broadcast events that interrupt the daily flow of television news and entertainment. They are live broadcasts of well-known, nationally or globally significant events that are covered consensually and uncritically with the acceptance of organizers,

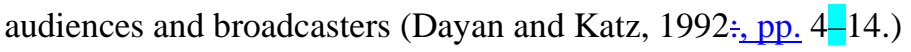

The consensus of a media event can be disrupted. Hijacking a media event means performing an act of protest that persuades the broadcasters to turn the cameras at the protestoers (Dayan and Katz, 1992, p.: 72). Hijacking an event was a logical thing to do for extremist dissidents in the broadcast era, when media events provided no channels for feedback or action to affect the course of the event. To simplify, the role of audience in a media event was to “'say amen_”- to the ceremony from the comfort of a living room sofa $;$; to 
dissent infrom the confines of the same sofa $a_{2} \div$ or to take it to the streets and hijack the event with symbolic violence. As Katz and Liebes (2007) famously point out, the terrorist attacks in at the Munich Olympics in 1972 were a typical hijacking of a media event. The case of the Gatecrashers demonstrates how disrupting a media event affects the nature of the event in today’s digitalized media environment.

If we look into the event from the point of view of Dayan and Katz's theory, we see that the celebration of Independence Day is a typical annual media event with features of civil religion (cf. Dayan and Katz, 1994). The occasion is highly ceremonial: the reception gathers close to half of the country's population of five million around their television sets to celebrate the interruption of routine and transformation of life into something special on this day off work. The live, pre-planned event invites the audience to commit themselves to the core value of consensus, $=$ or $_{2}$ more precisely ${ }_{2}$ a consensual understanding of the history of the independence of the nation, divided by the-civil war in 1918, but united again by the 'Miracle of the Winter War'. The majority of the programme consists of the line of guests shaking hands one--by_-one with the presidential couple as commentators (in their voice-over) explain who is who. There is also a design specialist present providing commentary on the female guests' gowns and their designers. As a media event, the televised reception sustains the nation symbolically by bringing together the elites and making them visible. The hegemonic media event invites the public to approve the authority and legitimacy of the presented-national decision--makers, heroes and celebrities presented (cf. Dayan and Katz,

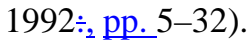

The theory of Dayan and Katz, as pertinent as it is in analysing classical media events = such as the funeral of President John_E. F. Kennedy ${ }_{2}$ or the wedding of Prince Charles and Lady Diana,_= provides little few conceptual tools with which to understand the mediated, real-time interplay of competing events and interpretations in today's digital media environment. Katz and Liebes (2007:-, p. 159) note that ceremonial media events are in a decline, being undermined by the tendency for action and interruption, rather than ceremony. As a result, the ceremonial and reverent media event is being replaced by live coverage of war, disaster and terror.

In recent years, circulation has been the focus of rising interest among media scholars, to the point where even 'the circulatory turn' (Straw, 2010) has been mentioned. The concept has been applied in attempts to understand the flux of meanings and information in such 
diverse phenomena as school shootings (Sumiala and Tikka, 2011), 'innovationism' (Valaskivi, 2012), media spectacles (Phillips, 2013), nation branding (Aronczyk, 2013; Valaskivi, 2013), management gurus (Kantola, 2013) and religious framing of media technologies (Campbell and La Pastina, 2010).

At its simplest, circulation can be defined as the 'going around' or passing of items, goods, artefacts, ideas or beliefs in the mediated world (Sumiala, 2008, 2013). The roots of the concept can be traced back to Marxist economics and structural anthropology (LéviStrauss, 1958; Marx, 1956_[1885]; Lévi-Strauss, 1958). Since the 1980s, the concept has been adapted by critical cultural studies (Hall, 1980; Johnson, 1986/1987 [1986]; Hall, 1980;Du Gay et al., 1997), and more recently by media anthropology and media studies (Gaonkar and Povinelli, 2003; Ahmed, 2004; Cronin, 2004; Lentin and Titley, 2011). It is a concept wellsuited to analyse communication in what has been described as the liquid modern era (Bauman, 2005). This era is signified with by the melting down of solid structures that are replaced with networks in a space of flows (Castells, 1996/2000[1996], 2009). Urry (2008) has argued along the same lines, claiming that we live in a world of mobilities. As 'cultures of circulation' are constitutive of the contemporary condition (Lee and LiPuma, 2002) and 'driving social change' (Aronczyk and Craig, 2013), the dynamic structures of circulation need to be studied (cf. Valaskivi and Sumiala, 2014). What we are interested in are the consequences of circulation. We take after Valaskivi and Sumiala (2014) in emphasizing that, through the circulation of meanings, representations, ideas, texts and images, mediated societies form the social imaginaries that sustain (and change) societies.

In studying the involvement of the Gatecrashers in the Independence Day media event ${ }_{2}$ we use the concept of circulation to understand which social imaginaries were sustained, challenged and created during the eccasionevent. The concept of circulation allows us to see the interaction across different, occasionally contradictory spaces and realms of meaning-making including the official vs.versus subaltern politics, the official broadcasting policy vsversus. the populist blogosphere and the ceremonial event vs.versus the disruptive event. We will return to the analysis of these elements further onlater in this chapter.

\section{Methodology}

By focusing on a dramatic media event, our aim is to study the dynamic space of negotiation between activists communicating mainly 
within their own circle of publicity and the so-called mainstream media, = television ${ }_{2}$ in particular. We examine 1) the actors and their roles in circulation ${ }_{2} ; Z$ )the physical and virtual places and spaces involved in the circulation ${ }_{2}$ and 3 ) the social imaginaries constructed through the circulation (or lack of circulation) of meanings and ideas within the media event.

In accord with the objective of tracing circulation, this study has a media ethnographic touch. As the events unfolded, we systematically gathered material available on the Internet, including social media platforms, news media and the blogosphere. Our empirical data of the case study consists of text, pictures and videos on Twitter, Facebook, blogs and mainstream media outlets before, during and in the immediate aftermath (ten 10 days) of the event (21 August--16 December, 2013). The method for data analysis is qualitative content analysis (Corbin and Strauss, 2008). The data was first close--read and open--coded for emerging themes. During a second round of coding, particular emphasis was placed on spaces and actors in creating and circulating social imaginaries. We traced the meanings in circulation through analysis of the actors involved actors-and the virtual and physical spaces and places through which the meanings flowed (or in which they were constrainedin). We also analysed the changes in meanings that took place in circulation.

In addition, in order to map the background for the emergence and circulation of messages, we extensively explored the counter-culture blogosphere linked to the organizers of the event. The main nodes in the counter-power blogosphere were identified by their prevalence in the information flow during the event and in the aftermath. Virtual ethnography (Hine, 2003; Sumiala and Tikka, 2011) and qualitative close--reading were carried out in order to trace and identify the main societal ideals and objectives in the blogosphere. This took the form of manual web crawling through outbound links from in-text hyperlinks and blog rolls, and inbound links established by search and web crawler tools.

All major national media outlets reported on the protests. Tweeting was active on \#kiakkovierasjuhlat and \#kiakkovieraat. Facebook debate was widespread and at least one ad hoc Facebook group was formed in the aftermath.

\section{Findings and discussion}

'Elitists partied so we beat up a horse. We did what we had to do' 
The sarcastic meme started circulating in social media while the protests were still ongoing. It was a virtual slap in the face of the protestorsers, who, simultaneously evoking a dutiful, lofty spirit of resistance against the oppressors, had beaten a police horse with hockey sticks.

The circulation of meanings in the Gatecrashers media event can be traced backwards and forwards in time, starting from the spark of violence at the gates of the venue of the presidential festivities venue. We also drill deeper in the 'moment of now' of that particular incident in order to analyse how real-time media flux affected real-life events. An early central node in the circulation of the Gatecrashers' message was their blog posting in August 2013, inviting people to join the demonstration (In the official presidential residence, 2013). It was widely referred to by media and bloggers both before and in the aftermath of the protests. Two thematic bundles of meanings, which were later circulated and transformed on various platforms, can be observed in these documents written months ahead of the event: class and emotions.

The Gatecrashers re-introduced class war as a political means and ends in a stable and egalitarian Nordic democracy. According to the anonymous blogger(s), the elite and the people exist as separate groups, and differences between them cannot be reconciled.

The early Gatecrashers' blog posts were full of emotions: anger, humour and carnivalesque violence. They balanced on the thin line between direct revolutionary calls and bitter jokes.

The Gatecrashers' blog reminds us that the division between the 'haves' and 'havenots' has been a fact since the civil war of 1918, when the revolutionaries were crushed in bloody battles in Tampere. According to the blog, the current government offers nothing but the stick to the poor: 'It has been a while since the elites came (to Tampere), following their massacring guards' canons, rifles and machine guns. Generations and years have passed and wine has flown in anniversaries instead of blood, but we do recognise them as the same bourgeois class and their lackeys.' (Iin the official presidential residence, 2013). The elite, the Gatecrashers claimed, dare to invite the people to celebrate Finland's independence by watching TV while the rich eat and drink at the expense of the poor. According to the Gatecrashers, these two worlds can never be united, and the victories the people have gained over the decades have been won only through the class war. The current leaders of the nation are represented as continuing the oppression of the workers by the far--right:- 
¿You have seen the picture of Hitler with butcher Mannerheim?[-] In Tampere he killed the workers struggling for food, freedom and equality. Now many Presidents after that, President Sauli Niinistö is having Suomi Finland party in Tampere. And only the rich and famous invited. And no dance! How boring is that! Sounds like work of whites! Stealing for themselves our tax money!'- (Invitation to the Ice Hockey, 2013) ${ }^{1}$

In the blog, the President of the Republic was depicted handcuffed on a burning grill. 'Let's barbecue!', the organizers glbeamed. 'Hockey and class war!', a masked and hooded ice hockey player declared in a meme picture, raising his hockey stick to hit; not a puck, but a bomb.

The blog posts call for invigorating the nascent protest movement against the Independence Day festivities in the early 2000s. The writer attempts to simultaneously bring the movement into the present day political context and establish the Gatecrashers as the real torchbearer of the WWHW World War II veterans' values of duty and love of the fatherland:-

-Finland is still a class society, even though wages have been raised, consumption has increased and the worst slave work has been moved to Asia. The rich party, the poor count their cents and the middle class fears falling from wellbeing to the street. The experiences in Southern Europe show that no one is safe when bankers have to be saved. [...-] We are on the side of the war veterans. We stand for equality, justice and freedom.- (Invitation to the Ice Hockey, 2013)

Their message was passionate and radical, and circulated and remediated the nationalist sentiments typical of the Independence Day festivities. The protestoers' message was not something everyone would accept, but it was something everyone could recognize because of the circulating symbolism they employed in their messages. This multifaceted style left room for mainstream media interpretation and reactions ranging from alarmist to sympathetic. The blog promised hockey slap shots in the face of the bourgeois and a barbecue party, leaving reporters from the mainstream media asking whether the anonymous would-be rioters were preparing for a real riot or a political performance.

As explained-above, the Independence Day celebration is the largest annual media event in Finland. It gathers nearly the entire adult population of the nation in front of its television sets with family members and friends who dress up for the occasion and prepare good food and festive drinks to discuss the procession of events, ladies' dresses and possible invited acquaintances.

Kommentti [mjh8]: AU: Does this appear in italics in the original?

No it does not appear in italics in the original

Kommentti [mjh9]: TE: This does not appear in the References section. As it is found in a blog, it is unclear how this information should be presented.

Should be referenced as Invitation to the Ice Hocke (n.d). Retrieved from http://kiakkovierasjuhlat.noblogs.org/inenglish-pa-svenska/

Muotoiltu: Display Extract

Kommentti [mjh10]: AU: Please confirm whether the source of the blog has been given accurately.

Yes

Should be referenced as Invitation to the Ice Hocke (n.d). Retrieved from

http://kiakkovierasjuhlat.noblogs.org/inenglish-pa-svenska/ 
The core value in the circulating social imaginary is celebrating reconciliation and the unity of the independent nation. They gaze towards the imagined, mediated centre of the society (cf. Shils, 1975; Couldry, 2003), represented by the invited guests of the party and sustained through the media.

Dayan and Katz (1992:, p. 7) note that the liveness-immediacy of a media event brings with it the possibility of interruption. Planning, rehearsing and ritualizing the event do not prevent something unexpected from happening. In 2013, the unexpected was designed devised by the protestoers with the aim of gaining attention through disturbing the ritual media event. The Gatecrashers had consciously planned their event to disturb and transgress the status quo and did this not only through media, but also through rioting outside $\theta$-the Tampere Hall during the festivities. From the point of circulation, this can be analysed as an act of disturbing the rehearsed practices of circulating consensual imagery, which were aimed at sustaining the social imaginary of the harmonious, unified nation. The actions of the protestoers were to some extent planned in advance- but, ${ }_{2}$ nevertheless, aimed at being

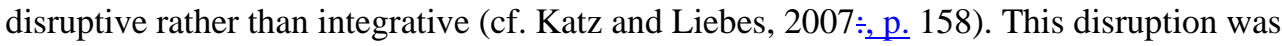
caused by providing alternative meanings to myths and symbols of independence already in circulation, as well as initiating circulation of alternative imagery.

Let us return, for a moment, to the 'now' - the outburst of violence.

While watching the hand-shaking procession taking place inside the Tampere $\mathrm{Hall}_{2}$ the television audiences could hear the rioters' shouts from outside. According to our realtime monitoring, YLE, however, did not report live on the events. Even the first television news programme aired during the celebration, including live coverage of the party, focused extensively on the presidential reception. Initially ${ }_{2}$ the riots were not mentioned, even when it was clear that news was breaking outside. A news event transgressed a media event, but the

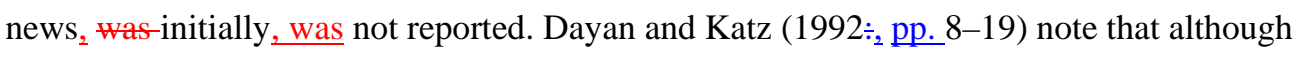
media events are hegemonic and have shades of political spectacle, the audiences have veto power over the interpretation of the events. Since the publication of Dayan and Katz's book, not only do the-audiences veto power in creating oppositional readings of hegemonic meanings of the media event, but they also possess the necessary equipment and skills to involve themselves - or even to cause disruption - with the actual cause of events. Thus, the protestoers were not the only ones that used social media during the event. 
The national broadcaster YLE was instantly criticized in social media, = on Twitter, in particular $_{,}=$for not having covered the riots. This criticism came both-not only from ordinary citizens, but also from journalists working in other mainstream news outlets. 'Dear \#yletv1, stop the tasteless presidential ball spectacle and move on to show the \#gatecrashers live', a tweeter posted. 'So, YLE did not mention at all the riots outside the festivities?' 2 a newspaper reporter at Helsingin Sanomat tweeted. His criticism was soon retweeted over 20 times. YLE later showed this tweet during its live broadcast from the Tampere Hall. Minutes later, YLE's social media producer mentioned the riots in his tweet for the first time, disapproving the vandalism: 'This is somehow so unnecessary. Demonstrators attacked Tampere Hall.' In his tweet, the journalist included a link to the first online news piece about the riots by YLE.

After this interaction, the news event had disrupted the ritual, ceremonial media event, and there was no turning back. A shift from the partying invited guests towards the protestoers outside took place in the news coverage, but not in the coverage of the ritual itself. When the violence then broke out, the media event included two scenes of breaking news, with competitive interaction on the interpretation of the events. A tweet with a link to a riot video also included the following comment: 'I felt bad about this small video clip. The police just rammed through people there _.....'. The message was retweeted once, whereas 'Some losers were pissed off in Tampere. It would be terrible to be a loser and cry/blame others about one’s own bad choices’ received 80 retweets and 129 favourites.

The incident involving the horses took place at a crucial moment. The rioters had advanced to the fences bordering the venue of the festivities. They had succeeded in drawing the mainstream media's attention to themselves. They had managed to bring into the circulation alternative imagery and thus influence the social imaginary related to the Independence Day celebrations. They were on a verge of opening open up discussion on who was and was not included in the mythical centre of the society. As police horses countered the protestoers in front of a barricade, several newspapers journalists and citizen journalists recorded the events on video. The protestoers slapped the horses with hockey sticks and threw paint bombs, beer cans and bottles at the horses. The police used teargas and batons against the protestoers. Two protestoers were run over by horses, receiving minor injuries. Three policemen required medical treatment for injuries. All six horses received minor injuries. 
Interpretations of the horse incident soon followed in different forms of media. They were now the face of the incident. Images of horses being beaten by masked protestoers with hockey sticks were circulated on YouTube, Twitter, Facebook and various news media websites. An anonymous commentator wrote the following comments in the chat room of the alternative website www.punkinfinland.net. 'It was annoying to watch how punks who make noise about animal rights slapped horses with hockey sticks'.

Muotoiltu: Ei alleviivausta

Kentän koodi muuttunut

Muotoiltu: Ei alleviivausta

Pictures of protestoers on social media were accompanied with the aforementioned sarcastic remark ‘'Elitists partied so we beat up a horse. We did what we had to do’, thereby marking the act as cowardly and purposeless. The responsibility of beating the animals was attributed to the protestoers as a collective. The social imaginary of nationalistic and historical references the protestoers had circulated to support their cause were turned against the Gatecrashers this time. A video interview of an intoxicated protestoer run over by a horse became a widely circulated and versioned item of jeerderision. The violence was represented as meaningless in comparison to-with the dutiful WWHI-World War II veterans' deeds.

Suddenly, the horses were the news, and their fate and recovery was followed in the news over the following days. Reference to historical war heroes gained a mocking tone and went as far back as the war of 1809 against Russia. A visual meme, picturing a decorated general on a beer can, ridiculed the intoxicated state of the protestoers: 'War Marshall Sandels leads his troops to Tampere. Beware.' Sandels is both a beer brand and a historical figure of the Finnish War of 1808 between Sweden and Russia.

Sarcastic historical allusions were particularly rich in visual memes. Protestoers were depicted alongside images of World War II cavalry veterans. News videos provided raw material to several YouTube mash-ups that combined real-time events and history with popular culture. Products included new versions of the ephemeral Hitler Learns meme from the movie Der Untergang, and The Lord of the Rings, in which horses collide with orcs in the Riots of Helm's Deep.

In the following days, the horses continued to gallop through several newspaper editorials, columns and the blogosphere. Editors used the fate of 'the innocent animals' to underline the recklessness of the protestors and their lack of any reasonedable message, as did mainstream media columnists and many bloggers. The police labelled the protestoers as 'organized crime'. Examples of editorials include the following: 
-The Gatecrashers did not present Finns any societal themes. People are now talking about how the protestoers wanted to hurt innocent animals'-

Editorial in the newspaper Kaleva (10 December, 2013)

-The youth have always protested. It is somehow part of civic participations, but brawling, breaking windows and beating of horses, even if they are 'police horses', is not even real anarchism².

Editorial in the newspaper Satakunnan Kansa (10 December; 2013)

The editorials were in unison in their view that the protestoers had no message. Naturally, this point had variations, but it can be generalized that editorial writers either outright concluded that the demonstrators had no message or that, if itone existed, it was left in the shadow of their rampant violence. In a somewhat contradictory manner, editorial writers were keen to circulate the concepts of class that the protestoers had re-unleashed: class society, class war and class struggle. By using these concepts, the ideals and objectives of the protestoers were cited and denounced. The laconic manner and lack of emotion in such critiques is notable.

The concept of elite was in wide use. While it is commonplace for editorial writers in Finland to express their concern of regarding widening income gaps, this time they found themselves on the other side of the barricade. In the editorial writers' thinking (half of them used this same point), there was no reason for the protestoers to express criticism of elitism, since there were unusually many 'ordinary people' invited to the presidential reception this time around. This can be interpreted as a strong countermeasure to prevent further anarchistic ideas from entering the circulation and thus altering the social imaginary of the nation and disturbing the ritual ways of celebrating independence.

The 'no-message' view of the editorial writings presents a striking contradiction to the abundance of political messages in the counter-power blogosphere that surrounds (through hyperlinks and circulation of meanings) the Gatecrashers' Internet presence. Many of the blogs present scholarly or otherwise thoughtful reflections on leftist radicalism and anarchism, analysis of the contemporary world, methods used to counter power and the objectives of their movement. Gender equality, counter-cultureeulture, ecology and income equality are recurring themes. ${ }^{2}$ The message of the editorials, however, was in unison with the dismissive tone of most of the circulating memes and jokes in the social media. 
To add to this pre-existing subculture, a reactionary blogosphere emerged in response to these events. Writers were political activists, scholars and 'ordinary people' who were inspired to weigh the events. Bloggers attempted to explain the use of relatively incidental and mild violence against police and animals as a necessary evil, and blamed the police for provoking violence. The events were contextualized and analysed in historical abundance. Many of these explanations centred on why Tampere was such a likely location for this type of an outburst. Some bloggers made references to Tampere having a historically active anarchist subculture. Others pointed out that the deep-running and unresolved frictions in Finnish society, which were last seen in mass demonstrations during the Great Recession of 1990, were perhaps rising to the surface once again. Many bloggers attempted to build a historical continuum of anarchist and leftist resistance from the early 1970s to date, analysing why the movement had been underground in Finland for a few years and whether it was now time for a new outburst of activism.

These perspectives, whichere-conveyed through memes and analyses by bloggers, while not all objective or balanced in their views, brought new information and context to the events. This was particularly clear in comparison with the newspaper editorials, which provided little political or historical reflection on the events and claimed, without investigating the phenomenon thoroughly, that there was no message to be found.

\section{Discussion}

The social imaginary of the Independence Day celebration of Finland is traditionally clear and simple: the focus is on the core value of consensus and the coming together of the whole, reconciled nation to celebrate the honourable history of gaining and sustaining independence together. The ritual is an integrative 'performance of symbolic acts' (Dayan and Katz, 1992: 12) relevant to the nation's core values. These symbolic acts include the orderly fashion in which the invited guests enter the festivities in the order of rank and seniority to shake hands with the presidential couple; the rehearsed representation of the festivities, including YLE reporters interviewing the guests with the classic question 'What does independence mean to you?' ${ }_{2} ;$ and even the commentary on the design and style of the dresses.

Our attempt has been to analyse the Independence $\underline{D}$ day media event and the news event created by the Gatecrashers through 1)actors and their roles in circulation $;$;2) the physical and virtual places and spaces involved in the circulation ${ }_{2}$ and 3 ) the social 
imaginaries constructed through the circulation (or lack of circulation) of meanings and ideas within the media event. Firstly, in relation to the actors involved-zctors, it is apparent that in this case the circulation involves contradictory positions. Initially, the actors line up according to their pre-planned media event roles. It is, however, apparent that the ongoing circulation of meanings and the development of events challenged the position of actors and forced them to adapt to the changing situation (cf. Valaskivi and Sumiala, 2014). The role of journalists in the national broadcasting company was challenged through the disruption caused by the protestoers, thus forcing them to adjust their practices both in the social media and in newscasts. This shows how the live broadcasting of a media event creates the sense of immediacy; but $_{2}$ at the same time ${ }_{2}$ the carefully planned, rehearsed and annually repeated media event is vulnerable to interruptions and changes of plans. This is where the Gatecrashers consciously aimed; they planned and executed a news event that penetrated the ritualized media event and, for a while, questioned the steady causerepetitive nature of the ceremony. The circulated image of the role of the demonstrators, however, changed during the cause course of events. In order to return to the status quo, the mainstream media ridiculed them for simply as being hooligans with no message. The circulation of wellthoughtconsidered discussions in the alternative blogosphere thus never entered the mainstream media.

Secondly, in relation to the spaces of circulation, technology can be viewed as not only a mediator between journalists, citizen journalists, protestoers and partiers (Latour, 1994, 2005), but also an actor. Technology created a space where the real-time interaction of all parties was possible but also defined the particular forms that the interaction tookplace. The planned, broadcast media event continued mostly interrupted, while social media gave citizens and individual journalists eapabilities-the ability to influence the flow of events and imaginaries in real time.

We argue that, by using their own media outlets, the Gatecrashers attempted to use the social imaginary of the ceremonial, ritual celebration of Independence Day to evoke sympathy for their cause of for greater equality in Finnish society. At the same time, the mainstream media remained in the ritual mode of the ceremonial celebration ${ }_{2}$ with journalists conforming to the consensual value of reconciliation at the core of this particular media event (cf. Dayan and Katz, 1992:- p. -7). The YLE and the national dailyies newspapers thus ended 
up interpreting the anarchists' actions as a transgressive disturbance to the event and quickly brushed off their efforts by declaring that their message was unclear.

In spite of the new power technology gave to the actors, the media event rehearsed and ritualized over the decades continued as if though nothing were happening outside of the venue. It was not the live Independence Day reception coverage- which reported the developments outside of the Tampere Hall, but the television news that eventually took on the demonstrations after pressure through social media. Thus, the potential immediacy of live television coverage was utilized to sustain the ritual media event and not to disturb the circulation of meanings contradicting the consensual ceremony. The event was created to sustain power and it continued to do so despite the developments outside.

The social imaginary utilized by the Gatecrashers also had wider connections. Imaginaries circulated over time and geographical boundaries. The blogosphere sympathetic towards the demonstrators had been developing the rhetoric and methods of anarchist and radical leftist activism for several years in Finland. This subculture was well_-connected internationally, particularly with European and American activist and countercultural blogospheres.

Thirdly, the case shows competing social imaginaries in action. It demonstrates how attempts to gain attention take place through instilling-putting alternative meanings into circulation. Actions were planned for real-time media consumption, interpretation and interaction. Official politics was challenged with subaltern politics through circulating alternative interpretations of Independence Day symbols and rituals. For instance, a class war was reinitiated with the help of historical imaginaries and symbolic violence. The beating of the horses, policemen and protestoers was inseparable from the imaginaries created at that moment. Violence itself became a symbol open for constant interpretation and reinterpretation.

During the event itself, the Gatecrashers utilized the historical social imaginary typical of the Finnish Independence Day celebrations. The historical events, war heroes and nationalist sentiment were all part of their message in which they attempted to raise discussion of inequality and access to the centre of society. They recycled and remediatedmediated these meanings to fit their own purposes. Messages circulated on a multitude of 
platforms through time and space. Messages were shared, commented and modified on social media, in constant interaction with mainstream media.

For a while, it seemed that the strategy would be successful and the mainstream media would listen to the demonstrators. The tipping point, however, took place when the demonstrations turned into riots, violence and vandalism, with windows smashed in and police horses attacked. The call for class war was ridiculed and the protestoers were said to have no real message. The emotional energy was dampened dumbed down by a laconic and patronizing treatment. In other words, the turn of events provided a chance for the mainstream media to contain the threatening, transgressive disturbance to the consensual media event.

Social theory discussed on the anarchists' blogs was not brought into the limelight by editorial writers or columnists; in fact, quite the opposite occurredreverse. If we analyse the course of events from the ritualistic point of view, we can see that the riots were a threatening disruption to a symbolic, integrative media ritual, which aimed at solidifying the core value of societal consensus and reconciliation within the nation. The riots questioned the unity of the nation and explicitly pointed out that it was the elites who were invited to the party, thus causing inequality. This argument was contested by several mainstream media writers as well as social media commentators, based on the fact that the president also invites 'ordinary people' every year. The contestation took a symbolic form with the aim of reinforcing the legitimacy of the ceremonial ritual.

Analysed from the point of view of media ritual, we can see symbolic action taking place on three levels. Firstly, there is the planned and rehearsed media event of the Independence Day celebrations disrupted by the riots. Secondly, violence used by both rioters and police was designed to be more symbolic in nature than an attempt to inflict great damage. Horses were mildly injured and caused minor injuries to protestoers, but the animals functioned in media circulation as symbols ranging from brutal power and oppression to innocence and humanity. Thirdly, we can see the mainstream media exercising its- symbolic power in quickly returning the balance in a ritualistic way, reducing the demonstrators to a marginal, un-important position by both silencing the messages of the riots and ridiculing the actions of the demonstrators as being meaningless vandalism. 


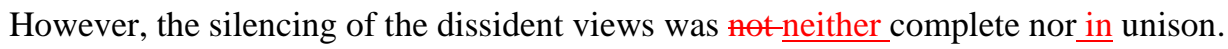
Meaningful dialogue and circulation of meanings took place between the rioters, professional journalists and social media users, transgressing physical boundaries, media genres and media platforms. We argue, that the Gatecrashers riots cannot be simply be understood as a hijacked media event. On the basis of our analysis, we suggest that the changed media technologies are giving visibility to alternative symbolic spaces (cf. Carey,_1998) and thus pessibilities as opportunities for a dialogical media event.

The Gatecrashers riots did contain elements of a hijacked media event. The demonstrators protested the consensual values of the presidential reception and used symbolic violence to gain attention and broadcast media coverage. However, in addition to hijacking a broadcast media event, the Gatecrashers created an alternative event and accompanying media content that provided channels for dialogue and new openings. Although the mainstream media was quick to dismiss this content, the disruption caused by the Gatecrashers had to be taken into account and also addressed also-in the wider publicity. In-For the lack want of a better expression, we call the whole - consisting of the integrative, symbolic media event and the disruptive media event (with features of hijack) - a 'dialogical media event'.

Based on our analysis, we observe a dialogical media event that is a product of interaction created between two events. The original event may sustain independently, and the alternative event contains features of a hijacking attempt. However, the interrelations of the two events are more complex than in a hijacked event.

To sum up, have collected in the following chartTable 6.1 presents the distinctive features of three types of media events from the perspectives of 1 ) the roles of key actors in circulation $_{2} ; 2$ ) places and spaces involved in circulation ${ }_{2} ;$ and 3 )__social imaginaries created through circulation. The typologies of the classical media event and the hijacked media event rely on Dayan and Katz (1992), while the typology of dialogical media event is abstracted from our case data.

Table 6.1- Typologies of Mmedia Eevents

\begin{tabular}{|l|l|l|l|}
\hline & Classical media event & Hijacked media event & Dialogical media event \\
\hline
\end{tabular}




\begin{tabular}{|c|c|c|c|}
\hline $\begin{array}{l}\text { Roles of key actors in } \\
\text { circulation }\end{array}$ & $\begin{array}{l}\text { Audiences perform } \\
\text { ceremonial roles, } \\
\text { renewing the contract } \\
\text { between the centref and } \\
\text { citizens. Journalists, } \\
\text { following expectations } \\
\text { of organizers, uphold } \\
\text { criticism for the tenure } \\
\text { of the event. }\end{array}$ & $\begin{array}{l}\text { Hijackers use broadcast } \\
\text { media to transgress and } \\
\text { question the media } \\
\text { event. Journalists are } \\
\text { challenged to report on } \\
\text { the news event instead } \\
\text { of the consensual media } \\
\text { event. }\end{array}$ & $\begin{array}{l}\text { Organizers of the } \\
\text { parallel event provide } \\
\text { news and memes for } \\
\text { social media circulation. } \\
\text { Audiences comment, } \\
\text { create their own version } \\
\text { and circulate messages. } \\
\text { A dialogue is opened } \\
\text { between broadcasting } \\
\text { journalists and social } \\
\text { media content creators. }\end{array}$ \\
\hline $\begin{array}{l}\text { Places and spaces } \\
\text { involved in circulation }\end{array}$ & $\begin{array}{l}\text { Homes, official venues } \\
\text { and live broadcast are } \\
\text { the central stages of } \\
\text { event. }\end{array}$ & $\begin{array}{l}\text { The locus of the } \\
\text { disruptive hijacking } \\
\text { attempt emerges as the } \\
\text { central place in the } \\
\text { event in addition to } \\
\text { homes, official venues } \\
\text { and original event } \\
\text { broadcast. }\end{array}$ & $\begin{array}{l}\text { Protests on the street, } \\
\text { broadcast and real-time } \\
\text { social media production } \\
\text { create a space efffor } \\
\text { interaction. Live } \\
\text { broadcast of the original } \\
\text { event may be sustained. } \\
\text { Social media content } \\
\text { gives national events a } \\
\text { global reach and } \\
\text { context. }\end{array}$ \\
\hline
\end{tabular}




\begin{tabular}{|l|l|l|l|}
\hline Social imaginaries & Consensual imaginaries & Irreverent and agonistic & Demonstrators, \\
constructed through & of reconciliation are & imagery is produced for & professional journalists \\
circulation & circulated on live & broadcast consumption. & \\
& broadcast television. & & and social media users \\
circulate and comment \\
on the consensual \\
\end{tabular}

By observing the emergence of a dialogical media event ${ }_{2}$ we do not claim that dialogue emerges in an ideal form. In the Gatecrashers case, the hegemony of the centre was hardly questioned for the majority of the live broadcast audiences. However, channels for dialogue were created where they previously did not exist, and they were used in novel ways. Rioters, television audiences and social media users played roles that were unimaginable two decades ago.

In the aftermath of the event, internationally circulated content and perspectives had a second life in ad hoc blog commentary and analyses, providing more historically reflective, politically contextualized and emotionally laden discussion than in mainstream media coverage. We argue that it is possible, if not even likely, that the Gatecrashers riots will be repeated in-at eoming future Independence Day receptions,_-_ becoming a ritualized event, as such. ${ }^{3}$ The circulation of meanings in the physical and media space outside the party venue was so widespread; that it is likely to affect how the event will be contextualized in the future. In subsequent national media events, such as the Independence Day celebration of 2014 and the May Day festivities in 2014 and 2015, we observe that anarchist protests were reported as naturalized (Alasuutari and Qadir 2014)_ and thus, perhaps, ritualized_ parallel media events. Similarly to the Gatecrashers’ riots, the 2014 Independence Day demonstrations had a theme - a 'Class trip from the suburbs to the President's official residence - that was communicated through the protestoers' own digital media. Violence, 
though constrained, was reported as part of the anarchists' methods and their protest against the 'hierarchical class society' referred to as business as usual.

Theoretically, our analysis suggests that the concept of circulation provides a fresh point of view to the study of media events in the digital age. It provides an possibility opportunity to look into the formation and sustaining of social imaginaries created through circulation, but also through restricting the flow of certain messages. It also affords possibilities-opportunities to see the power relations in ritual aspects of media events.

\section{Conclusion}

This chapter analyșzed the so-called ‘Gatecrashers riots’ that took place on 6 December, 2013 in Tampere, Finland. The event consisted of the annual televised media event of the presidential festivities of Independence Day presidential festivities, organized protests against the festivities, and interlinked media coverage and social media reactions. We used the concept of circulation in the context of a national media event to understand which social imaginaries were created, sustained; and challenged during theon that occasion.

The Gatecrashers planned and executed an alternative news event that penetrated a ritualized media event. The consensual celebration of national unity was challenged through circulating alternative interpretations of Independence Day symbols and rituals. Emotional outbursts, both planned and spontaneous, were circulated in forms of tweets, blogs and visual memes to reinitiate class war against the elites. Through real-time flows of meanings, for example on Twitter, the demonstrators managed to create a space where interaction between journalists, demonstrators, invitees guests to at the presidential ball; and audiences; took place and affected both events in real time. We argue that the Gatecrashers riots cannot be-simply be understood as a hijacked media event. Instead, we suggest athe typology of a_dialogical media event'. In the Gatecrashers riots, alternative symbolic spaces were used for meaningful interaction between two interlinked media events. We also argue that technology can be viewed as an actor, creating the space for circulation of alternative imaginaries in real-time and affecting the flow of events.

However, the dialogue was, all buton the whole, balanced or thorough. Our analysis indicates the violence of the rioters against the police and horses as a tipping point, after which the sympathies of both the mainstream media and social media commentators 
dampenedwaned. The mainstream media, newspaper editorials in particular, interpreted the anarchists' actions as a transgressive disturbance and quickly brushed them off by declaring that their message was either unclear - or non-existent. The circulation of discussions in the alternative blogosphere, to which the protestoers were linked, thus never entered the mainstream media. Furthermore, our analysis indicates that ${ }_{2}$ in spite of the emerging dialogical elements between the two media events, live television coverage was utilized to sustain the rehearsed and ritualized media event of the Independence Day celebration. The event was created to sustain the social imaginary of the unified nation and the-live television served this objective, despite the rioting outside of the venue and its eventual news coverage.

As a theoretical contribution to the field of studying contemporary media events, we suggest that the theory of media events benefits $\theta$ from considering the impacts of technological changes in the last two decades. The theory of media events was developed for analysing broadcast media events. Since Dayan and Katz, interactive digital media have provided channels for feedback and, as our analysis indicates, opportunities to affect the course of a media event by opening spaces and places of dialogue between actors able to create competing media events. The typology of _a_dialogical media event' is suggested as a tentative tool for analysing contemporary media events where social media interaction between the event, journalism and possible alternative media events are engaged in symbolic interaction in real-time on digital platforms.

\section{Acknowledgements}

The writers would like to thank Professor John Durham Peters for his insightful comments on an earlier version of this paper. Taneli Heikka's work for this study was supported by the Faculty of Humanities at the University of Jyväskylä.

\section{References}

Ahmed, S. (2004): ‘Affective eEconomies',- Social Text, 22(2): 117-139.

Alasuutari, P., and A. Qadir,A. (eEds.) (2014)(eds.) National Policy-Making. Domestication of 9 Global tTrends. London: Routledge.

Aronczyk, M. (2013) Branding the Nation: The Global Business of National Identity. Oxford University Press.

Aronczyk, M.2 and A. Craig, A. (2012): ‘Introduction: Cultures of €Circulation',- Poetics, 40(2): 2 ,93-100.

Bauman, Z. (2005)- Liquid $+\underline{\text { Life. }}$. Cambridge: Polity Press. 
Campbell, H., and A. C. La Pastina,A.C. (2010): ‘How the iPhone bBecame dDivine: New mMedia, rReligion and the ilntertextual $\in$ Circulation of mMeaning,': New Media and Society, 12(7):-), 1191-1207.

Castells, M. (1996, second edition, 2000): The Rise of the ANetwork s. Society; The

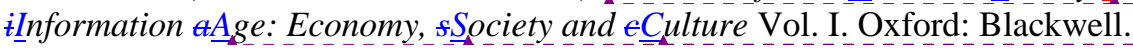

Gastells, M_ (2009) Communication pPower. Oxford: Oxford University Press.

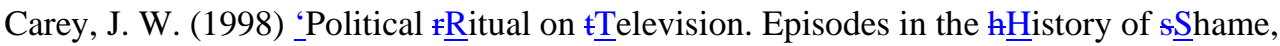
dDegradation and eExcommunication:’. In T. Liebes, T., J. Curran, J. and E. Katz, E. (eEds.), Media, rRitual and iIdentity. London: Routledge.

Corbin, J., and A. Strauss, A. (2008) Basics of Qualitative Research Techniques and Procedures for Developing Grounded Theory. Third $\underline{3 r d}$ Eedition $2_{2}:$ SAGE Publications

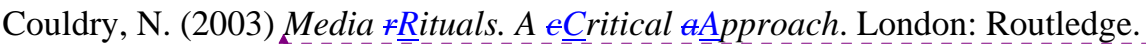

Cronin, A. (2004) Advertising mMyth: The strange hㅁalf-lives of $\underline{i}$ Images and $\in$ Commodities. London and New York: Routledge.

Dayan, D.2 and E. Katz,E. (1992)- Media eEvents. The tLive bBroadcasting of hHistory. Cambridge, MA: Harvard University Press.

DuGay, P., S. Hall,S., L. Janes, Ł.A. K. Madsen, H. Mackay, and K. Negus-et al. (1997); Doing $\in$ Cultural sStudies: The sStory of the Sony Walkman. London: Sage.

Gaonkar, D._P..2 and E. Povinelli, E. (2003): ‘Technologies of pPublic fForms: Circulation,

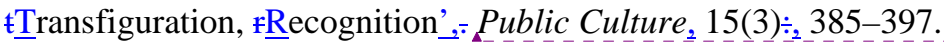

Hall, S. (1997): Representation: $€$ Cultural \&Representations and sSignifying pPractices. London: Sage.

Hine, C. (2003)- Virtual eEthnography. London: Sage.

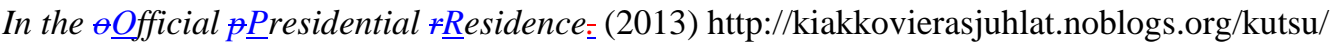
Retrieved 5 May, 2015.

Invitation to the Ice Hockey (2013) http://kiakkovierasjuhlat.noblogs.org/in-english-pasvenska/ Retrieved 5 May; 2015.

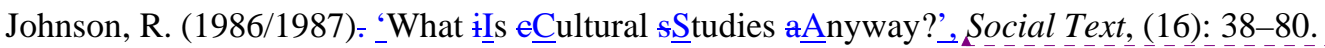

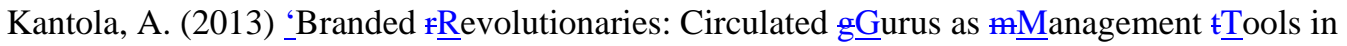
sSoft EeCEapitalism.', European Journal of Cultural Studies, 17(3): 258-274.

Katz, E., and T. Liebes, T. (2007) “"No mMore pPeace!”’- How ADisaster, hHave $\uplus$ Upstaged mpedia eEvents.' International Journal of Communication ${ }_{2} 1$ : 157-166.

Latour, B. (2005): Reassembling the sSocial - An iIntroduction to aActor-nNetwork-tTheory. Oxford University Press.

Latour, B__ (1994): ‘On tTechnical m

Lee, B.2 and E. LiPuma, E. (2002): 'Cultures of $€$ Circulation: The í Imagination of mModernity’, Public Culture, 14(1): 191-214.

Lentin, A., and G. Titley,-G. (2011): Crises of mMulticulturalism: Racism in a ANeoliberal aAge. London: Zed Books.

Lévi-Strauss, C. (1958)- Anthropologie sStructural. Paris: Plon.

\begin{tabular}{|c|c|}
\hline Muotoiltu & $\ldots[1]$ \\
\hline Muotoiltu & $\ldots[2]$ \\
\hline Muotoiltu & $\ldots[3]$ \\
\hline Muotoiltu & $\ldots[4]$ \\
\hline Muotoiltu & $\ldots[5]$ \\
\hline Muotoiltu & $\ldots[6]$ \\
\hline Muotoiltu & $\ldots[7]$ \\
\hline Muotoiltu & $\ldots[8]$ \\
\hline Muotoiltu & $\ldots[9]$ \\
\hline Muotoiltu & $\ldots[10]$ \\
\hline Muotoiltu & $\ldots[11]$ \\
\hline Muotoiltu & $\ldots[12]$ \\
\hline Kommentti [Q16]: AU: Please & $\ldots[13]$ \\
\hline Muotoiltu & $\ldots[14]$ \\
\hline Muotoiltu & $\ldots[15]$ \\
\hline Muotoiltu & $\ldots[16]$ \\
\hline Muotoiltu & $\ldots[17]$ \\
\hline Muotoiltu & $\ldots[18]$ \\
\hline Muotoiltu & $\ldots[19]$ \\
\hline Muotoiltu & $\ldots[20]$ \\
\hline Muotoiltu & $\ldots[21]$ \\
\hline Muotoiltu & $\ldots[22]$ \\
\hline Muotoiltu & $\ldots[23]$ \\
\hline Muotoiltu & $\ldots[24]$ \\
\hline Muotoiltu & $\ldots[25]$ \\
\hline Muotoiltu & $\ldots[26]$ \\
\hline Kommentti [Q17]: AU: "Hall & $\ldots[27]$ \\
\hline Muotoiltu & $\ldots[28]$ \\
\hline Muotoiltu & $\ldots[29]$ \\
\hline Muotoiltu & $\ldots[30]$ \\
\hline Muotoiltu & $\ldots[31]$ \\
\hline Muotoiltu & $\ldots[32]$ \\
\hline Muotoiltu & $\ldots[33]$ \\
\hline Muotoiltu & $\ldots[34]$ \\
\hline Muotoiltu & $\ldots[35]$ \\
\hline Muotoiltu & $\ldots[36]$ \\
\hline Muotoiltu & $\ldots[37]$ \\
\hline Muotoiltu & $\ldots[38]$ \\
\hline Muotoiltu & $\ldots[39]$ \\
\hline Muotoiltu & $\ldots[40]$ \\
\hline Muotoiltu & $\ldots[41]$ \\
\hline Muotoiltu & $\ldots[42]$ \\
\hline Muotoiltu & $\ldots[43]$ \\
\hline Muotoiltu & $\ldots[44]$ \\
\hline Muotoiltu & $\ldots[45]$ \\
\hline Muotoiltu & $\ldots[46]$ \\
\hline Muotoiltu & $\ldots[47]$ \\
\hline Muotoiltu & $\ldots[48]$ \\
\hline Muotoiltu & $\ldots[49]$ \\
\hline Muotoiltu & $\ldots[50]$ \\
\hline
\end{tabular}


Marx, K. (1956[1885])- Capital II: The pProcess of $€$ Circulation of $\in$ Capital. Moscow: Progress Publishers.

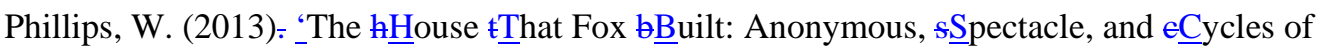
aAmplification',- Television and New Media, 14: 494-509.

Shils, E. (1975) ‘Center and pPeriphery. Essays in mMacrosociology’’, Selected Papers of Edward Shils, 2. University of Chicago Press.

Straw, W. (2010): ‘The Circulatory Turn', In B. Crow, B., $\underline{M}$. Longford, $M_{._{2}}$ and $\underline{\text { K. }}$ Sawchuck, K. (eEds.), The Wireless Spectrum: The Politics, Practices and Poetics of Mobile Media (pp. 17-28). Toronto: University of Toronto Press.

Sumiala, J. (2008) 'Circulation',- In Morgan, D. (eEd.) Keywords in Religion, Media, and Culture. London: Routledge.

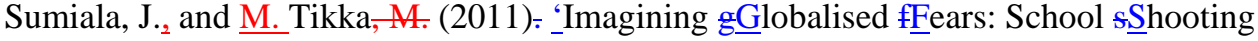
$\forall$ Videos and $€$ Circulation of $\forall$ Violence on YouTube',- Social Anthropology, 19(3): 254-267.

Taylor, C. (2002): ‘'Modern sSocial i̇maginaries',- Public Culture, 14(1): 91-124.

Urry, J. (2008)- Mobilities. Cambridge: Polity Press.

Valaskivi, K. (2012): ‘Dimensions of İnnovationism-’ In: P. Nynäs P, M. Lassander, $\mathrm{M}$ and T. Utriainen ${ }_{2}$ T (eEds.) ${ }_{2}$ Post Secular Society (pp. 129-156). London: Transaction, pp. 129 156. Available at:

http://tampub.uta.fi/bitstream/handle/10024/66384/dimensions_innovationism_2012.pdf?seq uence $=1$ (accessed 3 June 2013).

Valaskivi, K_ (2013): 'A bBrand nNew fFuture? Cool Japan and the s. İImaginary of the bBranded $\mathrm{n}$ Nation',- Japan Forum, 25(4), 485-504.

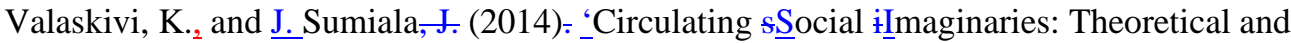
mMethodological fReflections',- European Journal of Cultural Studies, 17(3): 229-243.

\section{$\underline{\text { Notes }}$}

${ }^{1}$ This citation follows the English version of the blog post. http://kiakkovierasjuhlat.noblogs.org/in-english-pa-svenska/

${ }^{2}$ For an English or bilingual selection of these websites and themes, see, for example, the following links: http://takku.net/index.php?topic=In_English, http://dwardmac.pitzer.edu/Anarchist_Archives/index.html http://www.transformnetwork.org/home.html, www.zerohedge.com http://www.compassonline.org.uk www.revalvaatio.org http://yanisvaroufakis.eu, www.counterpunch.org http://fi.theanarchistlibrary.org http://nuvatsia.terevaden.net (Visited 4 May 2015).

${ }^{3}$ On 6 December 6,2014 the reception was back in Helsinki, where a group of about 200 people broke windows and caused other damage to property. The event received less media attention than in 2014 and was generally no longer called _-a riot' in the mainstream media. On the other hand, anarchists organized protest marches on the-1 May; 2015 innot only in the cities of Helsinki and Tampere, but also in the southern city of Turku. The demonstrations were mostly peaceful.
Muotoiltu: Fontti: Kursivoitu

Muotoiltu: Fontti: Kursivoitu

Muotoiltu: Fontti: Kursivoitu

Muotoiltu: Fontti: Kursivoitu

Muotoiltu: Fontti: Kursivoitu

Muotoiltu: Fontti: Kursivoitu

Muotoiltu: Fontti: Kursivoitu

Muotoiltu: Fontti: Kursivoitu

Kommentti [Q18]: AU: "Taylor 2002"

is not cited in the text. Please check

Remove it from the list

Muotoiltu: Fontti: Kursivoitu

Muotoiltu: Fontti: Kursivoitu

Muotoiltu: Fontti: Kursivoitu

Muotoiltu: Fontti: Ei Kursivoitu

Muotoiltu: Fontti: Kursivoitu

Muotoiltu: Fontti: Kursivoitu

Muotoiltu: Head1

Kentän koodi muuttunut

Kentän koodi muuttunut

Kentän koodi muuttunut

Kentän koodi muuttunut

Kentän koodi muuttunut

Kentän koodi muuttunut

Kentän koodi muuttunut

Kentän koodi muuttunut

Kentän koodi muuttunut

Kentän koodi muuttunut 
Fontti: Kursivoitu

Sivu 143: [2] Muotoiltu

Editorial_Integra

14.10.2015 15:04:00

Fontti: Kursivoitu

Sivu 143: [3] Muotoiltu

Editorial_Integra

14.10.2015 15:04:00

Fontti: Kursivoitu

Sivu 143: [4] Muotoiltu

Editorial Integra

14.10.2015 15:04:00

Fontti: Kursivoitu

Sivu 143: [5] Muotoiltu

Editorial_Integra

14.10.2015 15:04:00

Fontti: Kursivoitu

Sivu 143: [6] Muotoiltu

Editorial_Integra

14.10.2015 15:04:00

Fontti: Kursivoitu

Sivu 143: [7] Muotoiltu

Editorial_Integra

14.10.2015 15:04:00

Fontti: Kursivoitu

Sivu 143: [8] Muotoiltu

Editorial_Integra

14.10.2015 15:04:00

Fontti: Kursivoitu

Sivu 143: [9] Muotoiltu

Editorial_Integra

14.10.2015 15:04:00

Fontti: Kursivoitu

Sivu 143: [10] Muotoiltu

Editorial_Integra

14.10.2015 15:04:00

Fontti: Kursivoitu

Sivu 143: [11] Muotoiltu

Editorial_Integra

14.10.2015 15:04:00

Fontti: Kursivoitu

Sivu 143: [12] Muotoiltu

Editorial_Integra

14.10.2015 15:04:00

Fontti: Kursivoitu

Sivu 143: [13] Kommentti [Q16]

Editorial I ntegra

6.10.2015 23:55:00

AU: Please provide publisher location for this reference.

California, London, New Delhi, Singapore

Sivu 143: [14] Muotoiltu

Editorial_Integra

14.10.2015 15:04:00

Fontti: Kursivoitu

Sivu 143: [15] Muotoiltu

Editorial_Integra

14.10.2015 15:04:00

Fontti: Kursivoitu 
Fontti: Kursivoitu

Fontti: Kursivoitu

Fontti: Kursivoitu

Fontti: Kursivoitu

Fontti: Kursivoitu

Sivu 143: [21] Muotoiltu

Fontti: (Oletus) Times New Roman, 12 pt, englanti (Iso-Britannia)

Sivu 143: [22] Muotoiltu Editorial_Integra

14.10.2015 15:04:00

Fontti: Kursivoitu

Sivu 143: [23] Muotoiltu Editorial_Integra

14.10.2015 15:04:00

Fontti: Kursivoitu

Sivu 143: [24] Muotoiltu Editorial_Integra

14.10.2015 15:04:00

Fontti: Kursivoitu

Sivu 143: [25] Muotoiltu Editorial_Integra

14.10.2015 15:04:00

Fontti: Kursivoitu

Sivu 143: [26] Muotoiltu Editorial_Integra 14.10.2015 15:04:00

Fontti: Kursivoitu

AU: "Hall 1997" is not cited in the text. Please check.

Remove it from the list

Fontti: Kursivoitu 
Fontti: Kursivoitu

Sivu 143: [31] Muotoiltu

Editorial_Integra

14.10.2015 15:04:00

Fontti: Kursivoitu

Sivu 143: [32] Muotoiltu

Editorial_Integra

14.10.2015 15:04:00

Fontti: Kursivoitu

Sivu 143: [33] Muotoiltu

Editorial_Integra

14.10.2015 15:04:00

Fontti: Kursivoitu

Sivu 143: [34] Muotoiltu

Editorial_Integra

14.10.2015 15:04:00

Fontti: Kursivoitu

Sivu 143: [35] Muotoiltu

Editorial_Integra

14.10.2015 15:04:00

Fontti: Kursivoitu

Sivu 143: [36] Muotoiltu

Editorial_Integra

14.10.2015 15:04:00

Fontti: Kursivoitu

Sivu 143: [37] Muotoiltu

Editorial_Integra

14.10.2015 15:04:00

Fontti: Kursivoitu

Sivu 143: [38] Muotoiltu

Editorial_Integra

14.10.2015 15:04:00

Fontti: Kursivoitu

Sivu 143: [39] Muotoiltu

Editorial_Integra

14.10.2015 15:04:00

Fontti: Kursivoitu

Sivu 143: [40] Muotoiltu

Editorial_Integra

14.10.2015 15:04:00

Fontti: Kursivoitu

Sivu 143: [41] Muotoiltu

Editorial_Integra

14.10.2015 15:04:00

Fontti: Kursivoitu

Sivu 143: [42] Muotoiltu

Editorial_Integra

14.10.2015 15:04:00

Fontti: Kursivoitu

Sivu 143: [43] Muotoiltu

Editorial_Integra

14.10.2015 15:04:00

Fontti: Kursivoitu

Sivu 143: [44] Muotoiltu

Editorial_Integra

14.10.2015 15:04:00

Fontti: Kursivoitu 
Fontti: Kursivoitu

Sivu 143: [46] Muotoiltu

Editorial Integra

14.10.2015 15:04:00

Fontti: Kursivoitu

Sivu 143: [47] Muotoiltu

Editorial_I ntegra

14.10.2015 15:04:00

Fontti: Kursivoitu

Sivu 143: [48] Muotoiltu

Editorial_Integra

14.10.2015 15:04:00

Fontti: Kursivoitu

Sivu 143: [49] Muotoiltu

Editorial_Integra

14.10.2015 15:04:00

Fontti: Kursivoitu

Sivu 143: [50] Muotoiltu

Editorial_Integra

14.10.2015 15:04:00

Fontti: Kursivoitu 